\title{
Nutritional Qualities of Three Common Tomato Cultivars (UTC, Dan-Eka and Dan-Masari) in Dutsin-ma Local Government Area Katsina State
}

\author{
Q. Adebayo, L. T. Shittu, K. A. Sogunle, M. A. Taiwo, and I. K. Zubairu
}

\begin{abstract}
This work investigates the nutritional qualities of three common local tomato cultivars UTC, Dan -Masari and Dan-Eka in Dutsinma Local Government using standard techniques. The proximate, mineral, vitamins and lycopene contents were determined using AOAC method of analysis and the values were as follows. The moisture contents of the tomatoes were $95.56 \pm 0.16 \%, 93.85 \pm 0.12 \%, 93.97 \pm 0.61 \%$ for UTC, Dan-masari and Dan-eka respectively. Ash content were $0.36 \pm 0.03 \%, 0.47 \pm 0.06 \%, 0.51 \pm 0.09 \%$ respectively. Protein content were $0.99 \pm 0.04 \%, 0.73 \pm 0.07 \%$, and $0.79 \pm 0.79 \%$ in the same order. Total carbohydrate for UTC indicated values of $2.58 \pm 0.24 \%$, Dan-eka indicated value of $4.72 \pm 0.04 \%$ and Danmasari indicated values of $4.53 \pm 0.38 \%$. While the fat content showed $0.19 \pm 0.00 \%, 0.73 \pm 0.07 \%, 0.188 \pm 0.01 \%$ in that order. For vitamin $A$, the results were $19.80 \pm 0.73 \mathrm{mg} / \mathrm{kg}, 18.93 \pm 0.71$ $\mathrm{mg} / \mathrm{kg}$ and $15.49 \pm 0.24 \mathrm{mg} / \mathrm{kg}$ respectively. For vitamin $B_{2}$ and $B_{3}$ UTC has $0.003 \pm 0.00 \mathrm{mg} / \mathrm{kg}$ and $0.05 \pm 0.18 \mathrm{mg} / \mathrm{kg}$ in the same respect, Dan-eka showed $B_{2} 0.05 \pm 0.08 \mathrm{mg} / \mathrm{kg}$ and $B_{3} 0.15 \pm 0.20$ $\mathrm{mg} / \mathrm{kg}$ respectively while Dan-masari indicated $B_{2} \quad 0.000 \pm 0.00$ $\mathrm{mg} / \mathrm{kg}$ and $B_{3} 0.15 \pm 0.20 \mathrm{mg} / \mathrm{kg}$ and vitamin $C$ indicated values of $42.68 \pm 8.93 \mathrm{mg} / \mathrm{kg}$ for UTC, Dan-eka showed $52.82 \pm 3.60 \mathrm{mg} / \mathrm{kg}$ and Dan-masari showed values of $84.47 \pm 1.67 \mathrm{mg} / \mathrm{kg}$. The lycopene content UTC has the values of $116.01 \pm 1.59 \mathrm{mg} / \mathrm{kg}$, Daneka indicated $127.18 \pm 3.65 \mathrm{mg} / \mathrm{kg}$ and Dan-masari showed $91.36 \pm 2.24 \mathrm{mg} / \mathrm{kg}$. The mineral content for potassium indicated values of $3.74 \pm 0.28 \mathrm{ppm}, 3.40 \pm 0.16 \mathrm{ppm}, 3.08 \pm 0.61 \mathrm{ppm}$ for UTC, Dan-eka and Dan-masari respectively. For the iron content, $0.008 \pm 0.04 \mathrm{ppm}, 0.002 \pm 0.00 \mathrm{ppm}$ and $0.004 \pm 0.00 \mathrm{ppm}$ of UTC, Dan-eka and Dan-masari respectively. Magnesium values were $0.27 \pm 0.07 \mathrm{ppm}, \quad 0.22 \pm 0.16 \mathrm{ppm}$ and $0.25 \pm 0.02 \mathrm{ppm}$ correspondingly. For calcium, the obtained values were $0.26 \pm 0.04 \mathrm{ppm}, 0.26 \pm 0.05 \mathrm{ppm}, 0.38 \pm 0.07 \mathrm{ppm}$ respectively. The sodium contents were $0.18 \pm 0.02 \mathrm{ppm}, 0.18 \pm 0.08 \mathrm{ppm}, 0.30 \pm 0.13$ ppm in that order. These local varieties grown in Dutsinma are also good source of nutrient with no difference in the physiological quality parameters compared to the one been
\end{abstract}

Published on November 20, 2020.

Q. Adebayo, Department of Food Science and Technology, Federal University Dutsinma, Nigeria.

(e-mail: uncleq2001 ${ }^{\circledR}$ yahoo.com)

L. T. Shittu, Department of Food Science and Technology, Federal University Dutsinma, Nigeria.

(Email: lateefahshittu22@gmail.com)

K. A. Sogunle, Department of Food Science and Technology, Federal University Dutsinma, Nigeria.

(e-mail:ksogunle@fudma.edu.ng)

M. A. Taiwo, Department of Food Science and Technology, Federal University Dutsinma, Nigeria.

(e-mail: tmayomi@fudma.edu.ng)

I. K. Zubairu, Department of Food Science and Technology, Federal University Dutsinma, Nigeria.

(e-mail: idriszubairu09@gmail.com) imported. However, Dan-eka shows higher content of these nutrients in terms of lycopene and vitamin contents which makes it the best of these cultivars. However the results of this work suggest that three cultivars can provide good industrial raw materials for paste production because their total solids are within the range of specification and can meet daily recommended intake of lycopene and vitamin, moreover the low fat values for these samples gives it a positive nutritional implication.

Index Terms - Tomato, Nutritional, Lycopene, Minerals, Vitamins, Proximate Analysis.

\section{BACKGROUND OF THE STUDY}

Tomato is a fruit of the plant Solanum lycopersicum. The fruit has been noted as one of the most important nutritious crops consumed by humans. The word "tomato" comes from the Nahuatl word, literally known as "the swelling fruit" which belongs to the Solanaceae family. It is widely cultivated in many home gardens and in different fields due to its adaptation to broad range of soil types. It is usually cultivated in all climates and regarded number three top most produced fruit vegetables worldwide [1].

The tomato crop is relatively perishable and can maximally last for three weeks. In Nigeria, tomato is among the famous most utilized fruit vegetable, although it is produced very low in comparison to the yield of the temperate areas due to geographical differences, inadequacy of high yielding varieties and other practices such as traditional and cultural practices in its production [2], the production areas include most northern parts of the country which include Benue, Bauchi, Borno, Kano, Kaduna, Sokoto, Sokoto, Plateau, and also in few southern states including Kwara, Delta, and Oyo [3]. Tomato is considered as the most important vegetable superseded by onions and pepper [4]. The essential nutrients such as moisture, acidity, vitamin $\mathrm{C}$, crude fibre, protein, and lycopene generally vary with cultivars, cultural and postharvest handling practices.

Organic acids containing foods highly resist the survival of most pathogenic microorganisms and state the condition of available dominant micro flora in foods. As the vegetables and fruits get matured, the levels of the acids also decreased, while the simple sugars levels increase. The vitamin $\mathrm{C}$ which also called ascorbic acid is an organic acid commonly found in almost all fruits and most vegetables. Tomato is among the important fruit vegetables source of ascorbic acid and many physiological, sensorial and storability of tomatoes is 
attributed to its ascorbic acid content. The reducing ability of the ascorbic acids facilitates its maintenance of the enzyme prolylhydroxylate in an active state and making sure that the iron atom is in a reduced form. The presence of the acid also ensures the effective performance of the enzyme involved in the formation of collagen as a result of its ability to keep all vitamins in a soluble and stable form [5]. Moisture is a constituent of foods that play many vital roles more importantly in the aspect of food processing. In tomato processing, the moisture content serves many functionalities as it is an indicator that dictates its biochemical reactions, storability, and rheological changes in the tomatoes and its products. The ingestion of dietary fiber from variety of foods such as tomato prevents colon cancer, heart disease and normalizes blood lipids thereby reducing cardiovascular diseases. Therefore, the introduction of fiber rich foods in child's early life and continued consumption of these foods later in life has been encouraged [6].

Lycopene is the red pigment compound found in tomatoes. The compound is a hydrocarbon with elongated conjugate double bond as the carotenoids [7]. Being a fat soluble component, lycopene has absorption property similar to that of dietary fat. It is usually separated from the food matrix when ingested into the stomach and subsequently lower part of small intestine where it becomes dissolved in the lipid phase [8]. Processing of food industrially is among the factors that affect the bioavailability of many nutrients such as lycopene in tomato processing and hence increase absorption. This can be understood where the heat applied during processing induced the change of all trans-lycopene to cisisomers in the process called isomerization which positively affects its bioavailability [9]. Adequate intake of lycopene and vitamin A rich foods or its dietary supplementation is helpful in patients suffering from asthma and rheumatoid arthritis diseases and has been studied to be harmless when used as additive in foods [10].

Tomatoes add to healthy and well-balanced diet [11] as they contained many essential micronutrients, amino acids, sugars, and dietary fibers in measurable quantity. Also in respect to the findings of the United State Department of Agriculture on National Nutrient Database, tomatoes are naturally loaded with various nutrients including fiber, vitamin $\mathrm{A}$ and $\mathrm{C}$, potassium providing about one-fifth of the daily minimum requirement of vitamin $A$ based on a 2 kilocalorie dieting plan. Also, a medium size tomato can provide about one-quarter of the daily recommended levels of vitamin C intake [12].

Although tomato is edible alone or added in salads or in related foods in its fresh form, Processing can be considered necessary due to its shorter storability and mostly as a result of high production which largely influences market glut especially in its cultivation season leading to greater lost by the producers. Therefore, it can be processed and exported to other nearby African countries or marketed within the country because of the high local demand. Varieties of products can be obtained through processing of tomatoes ranging from puree, Ketchup, powder to juice of various packaging designs. It serves a good component of most people's daily diet [13].
In recent times, the Dan-eka, Dan-masari and UTC cultivars have become very popular among farmers in Dutsinma local government and this study has been designed to ascertain the proximate composition of some key factors that can determine their use for both domestic and industrial purposes. Therefore, this research is based on the three common varieties of tomato (Dan-eka, Dan-masari and UTC) prevalent in Dutsin-ma local government. The common varieties are generally oval or cylindrical in shape, with significantly fewer locules (seed compartments) than standard round tomatoes (usually only two) and a generally higher solid content, making them more suitable for processing.

Dan-Masari tomato, is a medium-size, globe-type F1 hybrid, popular to home gardeners because of its early ripening characteristic. It is a cultivar of tomato with indeterminate growth, which means it produces flowers and fruit until it is killed by harsh weather or another external factor (contrast with a determinate cultivar, which would grow to a limited, predefined shape and be most productive for one large harvest before dying or tapering off with minimal new growth or fruit). It grows tall $(1.6$ to $2.0 \mathrm{~m})$. Therefore, it needs support as the plant grows. Fruit maturity ranges from 50 to 62 days after transplanting, depending on the source, which appeals to growers in climates with shorter growing seasons. The ripe fruit is extremely standard for a tomato, about the size and shape of a tennis ball and weighing 4 to 8 ounces (110 to $230 \mathrm{~g}$ ). The tomatoes have a bright color and good flavor.

Although knowledge has been acquired with regards to the level of vitamin $\mathrm{C}$, lycopene and mineral content both on the qualitative and quantitative aspect on various types of tomato, but the local varieties have little or no information on proximate, lycopene and mineral content despite the abundance of these tomatoes, there is still problem of micronutrient deficiency in Nigeria. There is need to identify and evaluate the nutrient, and food toxicant levels of some of these tomatoes. Tomatoes could be integrated in the foodbased approach for fighting micronutrient deficiency in Nigeria. This can also be useful information for food processors, nutritionist, and people of related fields.

This research work will expose the nutritional qualities of these tomato varieties to the rural community of Dutsin-ma locality where malnutrition is prevalent and the willing Industrial processors of the tomatoes. This study is limited to fresh tomato fruit (100\% ripe) of the common tomato fruit in Dutsin-ma Local Government.

\section{MATERIAls AND Method \\ A. Study Area and Description}

Dutsin-ma became a local government (in 1976) of the federal republic of Nigeria under Katsina state. It is among the top five most developed local governments Area in the State. The LGA has an Area and a population of about 527 $\mathrm{km}^{2}$ and 169,671 (2006 general census) respectively. It is located on co-ordinates $12.4545^{\circ} \mathrm{N} 7.4977^{\circ} \mathrm{E}$. The inhabitants of the local government are predominantly Hausa and Fulani tribes. Their main occupation is agricultural practices [14]. 


\section{B. Sample Collection and Preparation}

Three varieties of fresh tomatoes fruit (100\% ripe) were purchased from Trans-able farm in Ba-dole and Shongai farms of Dutsin-ma local government and the samples were properly washed and blended together using a food grade blending machine.

\section{Lycopene Determination Using Official Method}

Using [15] method of analysis, $1 \mathrm{~g}$ of the tomato samples was weighed and homogenize with distilled water in a $100 \mathrm{ml}$ volumetric flask and make up to mark. It was mixed well, and $10 \mathrm{ml}$ of the solution was transferred into the separating funnel. $40 \mathrm{ml}$ of distilled water was added into the separating funnel and shake. $25 \mathrm{ml}$ of ether was added into the separating funnel and shake vigorously and leave for 15 minutes. The aqueous layer was run off into a beaker. It was poured into cuvette and read using a UV- spectrophotometer. Calculation:

$$
\text { ABSORBENT } \frac{X 1000 X 100}{282 X 1.42 X 4 X W T}
$$

\section{Mineral Analysis}

The tomato samples were dry ashed using [15]. Sample analysis was done using AA240FS atomic absorption spectrophotometer (AAS) equipped with a hollow cathode lamp, current $10 \mathrm{~mA}$, wavelength $217 \mathrm{~nm}$, band pass $0.5 \mathrm{~nm}$, with a flame type consisting of air/acetylene and stoichiometric fuel flow at $0.9-1.2 \mathrm{dm}^{3} / \mathrm{min}$. Levels of Minerals (Iron, Potassium, calcium, Magnesium, Sodium) in the tomato samples were determined by weighing $1.0 \mathrm{~g}$ of the ashed samples into a digestion tube and digesting it with $10 \mathrm{ml}$ of a mixture of concentrated nitric acid $\left(\mathrm{HNO}_{3}\right)$ and concentrated $\mathrm{HCl}$ on a hot plate. On cooling, the digested sample was filtered using a whatsman filter paper into a 50 $\mathrm{ml}$ volumetric flask and made up to mark with distilled water. The filtration was aspirated into the AAS and levels of the minerals were determined.

\section{E. Moisture Content}

A dried cooled platinum dish was weighed $\left(\mathrm{w}_{1}\right)$ and $2 \mathrm{~g}$ of the test sample was introduced into the dish and weighed accurately $\left(\mathrm{w}_{2}\right)$. The dish and its content were transferred into an oven at $105{ }^{\circ} \mathrm{C}$ to dry for about 3 hours and the dish is removed and weighed $\left(\mathrm{w}_{3}\right)$ [15].

Calculation:

Percentage moisture $=w 2-w 3 / w 2-w 1 \times 100$

\section{F. Determination of Total Carbohydrate Content}

The percentage carbohydrates were obtained by difference [15]. The carbohydrate content was calculated using the following:

Total carbohydrate $=100-(\%$ moisture $+\%+\%$ ash + $\%$ protein $+\%$ fat $)$

\section{G. Ash Content Determination [16]}

$0.2 \mathrm{~g}$ of the homogenized samples was placed in a porcelain crucible and ash in a muffle furnace at $600^{\circ} \mathrm{C}$ for exactly 3 hours. The crucible container was then allowed to cool, and the weight of the ash taken by using before and after weights of both the crucibles containing the samples and the weight of the crucible alone.

\section{H. Crude Protein Determination}

$0.2 \mathrm{~g}$ of the blended homogenized samples were weighed into the digestion tubes followed by the addition of $5 \mathrm{~g}$ of Kjeldahl catalyst and $15 \mathrm{~cm}^{3}$ of concentrated $\mathrm{H}_{2} \mathrm{SO}_{4}$. Each tube was mixed thoroughly and then heated for 2 hours until the solutions became clear and $15 \mathrm{~cm}^{3}$ of $40 \% \mathrm{NaOH}$ was added to each of the samples. The mixture was allowed to cool and then transferred into $100 \mathrm{~cm}^{3}$ volumetric flask and diluted with distilled water to the mark. Another $10 \mathrm{~cm}$ of $2 \%$ boric acid was measured into $100 \mathrm{~cm}^{3}$ Erlenmeyer flask and few drops of Methyl red indicator were added. Furthermore, $10 \mathrm{~cm}^{3}$ of digested aliquot was transferred into a distillation apparatus and then distilled into the boric/indicator for 15 minutes. The distillate was then titrated with $0.025 \mathrm{M} \mathrm{HCl}$ to a pink end point [17].

\section{Fat Content Determination Using (Schmidt Method)}

2 grams of each of the samples was weighed into boiling tubes. $10 \mathrm{ml}$ of concentrated $\mathrm{HCl}$ was added and put in a water bath until solid particles dissolve and until mixture becomes brown. It was then taken off and cooled, then transferred into a separating funnel. $10 \mathrm{ml}$ of ethanol and $30 \mathrm{ml}$ of diethyl ether was added and shaken to dissolve; it was then allowed to stand for some minutes so to separate. A clean dried conical flask $\left(\mathrm{w}_{1}\right)$ is weighed, and the ether layer was transferred into the flask. The extraction was repeated twice with $25 \mathrm{ml}$ of diethyl ether and the extract was evaporated in a water bath to remove the diethyl ether. The fat is dried at $105^{\circ} \mathrm{C}$ in an oven, cooled and weighed $\left(\mathrm{w}_{2}\right)$.

\section{J. Vitamin A Analysis}

2 grams of the sample was weighed into the round bottom flask, $25 \mathrm{ml}$ of $0.5 \mathrm{M}$ alcoholic $\mathrm{KOH}$ was added to the sample, swirled and wrapped with foil paper. The solution was refluxed for 1 hour. After refluxing, 3 drops of phenolphthalein indicator were added to the solution and was titrated while hot with $0.5 \mathrm{M} \mathrm{HCl}$ until a colorless solution is obtained. $1 \mathrm{ml}$ of $3 \mathrm{M}$ aqueous $\mathrm{KOH}$ was added to the neutralized sample and was transferred to a separating funnel. The amount of acid used to neutralize the sample (titre value) was subtracted from $50 \mathrm{ml}$ and the resulting value of distilled water was added to the solution in the separating funnel. Extraction with $50 \mathrm{ml}$ diethyl ether was carried out thrice with vigorous shaking on each addition of the diethylether. The ether layer was washed three times with $20 \mathrm{ml} 0.5 \mathrm{M}$ $\mathrm{KOH}$. The resulting solution was washed continuously with $20 \mathrm{ml}$ portions of water until it was no longer alkaline to phenolphthalein (i.e. no pink color was observed when tested with phenolphthalein). The washed extract was evaporated over the water bath and reconstituted with $4 \mathrm{ml}$ of isopropanol. The absorbance was taken at $325 \mathrm{~nm}$ with the UV spectrophotometer. $\mathrm{E}_{1}=953$ [15]. 


\section{K. Vitamin B2 and B3 Analysis}

Using [15], $10 \mathrm{mg}$ of the Vitamin $\mathrm{B}_{2}$ (standard salt) was weighed into a $25 \mathrm{ml}$ volumetric flask, dissolved, and made to the mark with buffer solution and labeled as stock. $4 \mathrm{ml}$ of standard stock was transferred into $25 \mathrm{ml}$ amber volumetric flask, made to the mark with buffer solution, vortexed and labeled as intermediate mixed stock. With the use of the intermediate mixed stock solution, serial dilutions were carried out by pipetting $1 \mathrm{ml}, 2 \mathrm{ml}, 3 \mathrm{ml}, 4 \mathrm{ml}$ and $5 \mathrm{ml}$ of the intermediate into 5 different $10 \mathrm{ml}$ volumetric flasks and made to the mark with the buffer solution, vortexed and labeled mixed working standard serially. They were then transferred into vials using syringe and a micro filter for each mixed working standards and then taken together with the samples to the HPLC for analysis. The same was carried out to determine the $\mathrm{B}_{3}$ content of the samples.

\section{Chromatographic condition}

Elution: isocratic, Wavelength: $214 \mathrm{~nm}$, Mobile phase: Methanol: potassium orthophosphate buffer (50:50),
Column: C18, $5 \mu \mathrm{m}$, ODS2, Flow rate: $1.2 \mathrm{ml} / \mathrm{minute}$, Injection: 3 times.

\section{Ascorbic Acid Determination}

$5 \mathrm{~cm}^{3}$ of the homogenized sample was added to $1 \mathrm{~cm}^{3}$ of acetic acid, using indophenol indicator it was titrated with 0.1 $\mathrm{M} \mathrm{NaOH}$ to the end point. Another $5 \mathrm{~cm}^{3}$ of standard ascorbic acid in an erlenmeyer flask was titrated with the indophenol until a faint pink color remained unchanged. These were done three times. The volumes of $\mathrm{NaOH}$ were used to calculate the ascorbic acid levels in both the standard and the samples [17].

\section{N. Statistical Analysis}

The results were expressed as mean \pm standard deviation. Significant difference was expressed by one way analysis of variance (ANOVA) followed by Duncan post-Hoc Descriptive Test using Statistical package for social science (SPSS) version 16.0.

\section{RESULTS}

A. Proximate Composition of the Samples

TABLE I: PROXIMATE COMPOSITION OF THE SAMPLES

\begin{tabular}{ccccccc}
\hline \multirow{2}{*}{ Samples } & Total Solid \% & Ash $\%$ & $\begin{array}{c}\text { Moisture } \\
\text { Content } \%\end{array}$ & Fat $\%$ & Protein \% & T.CHO \% \\
\hline UTC & $4.44 \pm 0.17^{\mathrm{b}}$ & $0.36 \pm 0.03^{\mathrm{a}}$ & $92.43 \pm 0.16^{\mathrm{a}}$ & $0.19 \pm 0.00^{\mathrm{a}}$ & $0.99 \pm 0.04^{\mathrm{a}}$ & $2.58 \pm 0.24^{\mathrm{b}}$ \\
Dan-masari & $4.12 \pm 0.14^{\mathrm{a}}$ & $0.47 \pm 0.06^{\mathrm{a}}$ & $90.75 \pm 0.12^{\mathrm{b}}$ & $0.21 \pm 0.74^{\mathrm{a}}$ & $0.73 \pm 0.07^{\mathrm{a}}$ & $3.72 \pm 0.04^{\mathrm{a}}$ \\
Dan-eka & $4.03 \pm 0.61^{\mathrm{a}}$ & $0.51 \pm 0.09^{\mathrm{a}}$ & $90.97 \pm 0.61^{\mathrm{b}}$ & $0.18 \pm 0.01^{\mathrm{a}}$ & $0.79 \pm 0.79^{\mathrm{a}}$ & $3.51 \pm 0.38^{\mathrm{a}}$ \\
\hline
\end{tabular}

Data expressed as mean \pm SD. The value with the same subscript shows that there is no significant difference (p $<0.05$ ). T.CHO from the table means Total carbohydrate.

\section{B. Lycopene and Vitamin Compositions of the Samples}

\begin{tabular}{|c|c|c|c|c|c|}
\hline Samples & $\begin{array}{c}\text { Lycopene } \\
(\mathrm{mg} / \mathrm{kg})\end{array}$ & $\begin{array}{c}\text { Vitamin A } \\
(\mathrm{mg} / \mathrm{kg})\end{array}$ & $\begin{array}{c}\text { Vitamin B2 } \\
\mathrm{mg} / \mathrm{kg})\end{array}$ & $\begin{array}{c}\text { Vitamin B3 } \\
(\mathrm{mg} / \mathrm{kg})\end{array}$ & $\begin{array}{c}\text { Vitamin C } \\
(\mathrm{mg} / \mathrm{kg})\end{array}$ \\
\hline UTC & $116.01 \pm 1.59^{\mathrm{a}}$ & $19.80 \pm 0.73^{\mathrm{a}}$ & $0.003 \pm 0.00^{\mathrm{a}}$ & $0.05 \pm 0.18^{\mathrm{a}}$ & $42.68 \pm 8.93^{b}$ \\
\hline $\begin{array}{l}\text { Dan- } \\
\text { masari }\end{array}$ & $91.36 \pm 2.24^{b}$ & $18.93 \pm 0.71^{\mathrm{a}}$ & $0.000 \pm 0.00^{\mathrm{a}}$ & $0.15 \pm 0.20^{\mathrm{a}}$ & $52.82 \pm 3.60^{b}$ \\
\hline Dan-eka & $127.18 \pm 3.65^{\mathrm{a}}$ & $15.49 \pm 0.24^{b}$ & $0.05 \pm 0.08^{\mathrm{a}}$ & $0.07 \pm 0.08^{\mathrm{a}}$ & $84.47 \pm 1.67^{\mathrm{a}}$ \\
\hline
\end{tabular}

\section{Mineral Composition of the Samples}

TABLE III: MINERAL COMPOSITION OF THE SAMPLES

\begin{tabular}{cccccc}
\hline Samples & $\mathrm{K} \mathrm{ppm}$ & $\mathrm{Fe} \mathrm{ppm}$ & $\mathrm{Mg} \mathrm{ppm}$ & $\mathrm{Ca} \mathrm{ppm}$ & $\mathrm{Na} \mathrm{ppm}$ \\
\hline UTC & $3.74 \pm 0.28^{\mathrm{a}}$ & $0.008 \pm 0.04^{\mathrm{a}}$ & $0.27 \pm 0.07^{\mathrm{a}}$ & $0.26 \pm 0.04^{\mathrm{a}}$ & $0.18 \pm 0.02^{\mathrm{a}}$ \\
Dan- & $3.40 \pm 0.16^{\mathrm{a}}$ & $0.002 \pm 0.00^{\mathrm{a}}$ & $0.22 \pm 0.16^{\mathrm{a}}$ & $0.26 \pm 0.05^{\mathrm{a}}$ & $0.18 \pm 0.08^{\mathrm{a}}$ \\
masari & & & & \\
Dan-eka & $3.08 \pm 0.61^{\mathrm{a}}$ & $0.004 \pm 0.00^{\mathrm{a}}$ & $0.25 \pm 0.02^{\mathrm{a}}$ & $0.38 . \pm 0.07^{\mathrm{a}}$ & $0.30 \pm 0.13^{\mathrm{a}}$ \\
\hline
\end{tabular}

Data expressed as mean $\pm \mathrm{SD}$. The value with the same subscript shows that there is no significant difference $(\mathrm{p}<0.05)$.

\section{DISCUSSION}

\section{A. Proximate Composition of the Samples}

Moisture, the mean moisture contents of the samples as shown in table 1 were found to range from $95.56 \%$ to 93.85 $\%$. The high moisture content of the samples was as expected with no significant difference at $\mathrm{P}<0.05$ between the local varieties (Dan-eka and Dan-masari) and the imported UTC variety meaning they can equally serve the same purpose. Fresh fruits and vegetables are known to contain higher moisture relative to sun or shade dried samples [18]. The moisture content of the samples is in conformity with the findings of [19].

Ash content gives an indication of the mineral composition preserved in the food materials [20]. The ash content of the samples ranges from $0.51 \%$ to $0.37 \%$ with no significant differences at $\mathrm{P}<0.05$ between the local and the imported UTC variety samples have lower ash content which might be as a result of higher water content of the samples, the result in this research work is in agreement with that of [21], [22].

The total solids indicate the amount of solids in the samples aside water, the result was as expected as water been the major composition of the samples, the total solids which ranges from $6.12 \%$ to $4.44 \%$ at $\mathrm{P}<0.05$ significant difference, the difference between the local varieties and the imported UTC varieties is little which shows that both can be utilized same way industrially or at home level. The work is in conformity with that of [23].

The samples contain fat component which ranges from $0.218 \%$ to $0.188 \%$ with no significant difference at $\mathrm{P}<0.05$ 
between the control and the local varieties, The low fat content of the samples was not a surprised as fruit and vegetable are not good source of fat [24]. The fat values of the studied work are comparable to the observations of [19].

Fresh tomato proteins of the samples range from $0.99 \%$ to $0.73 \%$ with no significant difference at $\mathrm{P}<0.05$ between the imported UTC variety which is the control and local varieties. The low protein content of the tomato samples was as expected, and the high moisture content of the fruit sample was the major cause of low protein. It is known that the lower the moisture content of a given food the higher is the protein. As reported by [25], moisture affects nutrient content of fruits. Generally, all the fresh fruits are low in protein because they contain more moisture and less when they are dried. Similar result was reported by [26].

The total carbohydrate (T.C) of the samples ranges from $4.72 \%$ to $2.90 \%$ with UTC having the least and with significant difference at $\mathrm{P}<0.05$. The low carbohydrate value of the tomato samples may be attributed to its high moisture that lowered its dry matter of which carbohydrate belongs to them. This observation is in line with those of some researchers like [27] who reported that high moisture of a given food, affects its dry matter adversely of which carbohydrate is among. Similar report was recorded by [26].

\section{B. Vitamins Composition of the Samples}

The vitamin A values of the samples ranges from $19.80 \%$ to $15.49 \%$ with Dan Masari having the least and little significant difference between the control and the local varieties at $\mathrm{P}<0.05$. The high pro-vitamin $\mathrm{A}$ in the samples have many positive nutritional impacts; it showed that these particular tomato fruits could be good sources of pro-vitamin A mostly for the region where it is cultivated. The values found in the present study were similar to the ones reported by [17].

Vitamin $B_{2}$ of the samples ranges from $0.009 \mathrm{mg}$ to $0.003 \mathrm{mg}$ and Vitamin $\mathrm{B}_{3}$ has values ranging from $0.46 \mathrm{mg}$ to $0.07 \mathrm{mg}$, the low values of these vitamins can be as a result of Cultivars as well as sun light as it has effect in the vitamins formation. Nevertheless, the result seemingly tallies with the one obtained by [28].

The vitamin $\mathrm{C}$ values of the tomato samples ranges from $84.47 \mathrm{mg}$ to $42.68 \mathrm{mg}$ with little significant difference between the control and the local varieties at $\mathrm{P}<0.05$. The high ascorbic acid of the samples strongly suggest that it could be good cheap source of the nutrient to address ascorbic acid deficiency. As little as 5 to $10 \mathrm{mg}$ ascorbic acid daily intake can combat scurvy. Tomato fruit can be used as a tool to easily meet $40 \%$ of an adult's body requirement by providing $60 \mathrm{mg}$ of ascorbic acid and two-third of the children's daily requirement that is about $40 \mathrm{mg}$ per day [29]. This result is higher than those reported by [29] which can be as result of environmental factors.

\section{Lycopene}

Lycopene content of the samples includes Dan-eka having the highest lycopene content of $127.18 \mathrm{mg} / \mathrm{kg}$ followed by UTC with content of $116.01 \mathrm{mg} / \mathrm{kg}$ compared to Dan-masari having the least value of $91.36 \mathrm{mg} / \mathrm{kg}$. This result is in conformity with that of [30]. According to [31], daily intake of one or more serving of tomato, tomato product or lycopene supplement may play a role in the prevention of prostate cancer.

\section{Mineral Composition of the Samples}

The results for the sodium in the tomatoes samples ranges from $0.30 \mathrm{ppm}$ to $0.18 \mathrm{ppm}$ with no significant difference statistically between the imported UTC and the local varieties at $\mathrm{P}<0.05$. The low sodium values of the samples could be as a result of nutritional level of the soil. The varieties could be considered safe for hypertensive patient, thus should be included in their meals as higher sodium diets increases blood pressure. This result shows a lower concentration with regards to the one stated by [32]. The result values for potassium, iron, magnesium and calcium were comparatively low in UTC, Dan-eka and Dan-masari tomato samples which ranged from $3.74 \mathrm{ppm}$ to $3.08 \mathrm{ppm}, 0.008 \mathrm{ppm}$ to $0.002 \mathrm{ppm}$, $0.27 \mathrm{ppm}$ to $0.22 \mathrm{ppm}$ and $0.38 \mathrm{ppm}$ to $0.26 \mathrm{ppm}$ respectively, the low values of these minerals might be due to the environmental factors. Although the result of this study is in line with the one discovered by [29], the amount of minerals contained in fruits and vegetables depend on variety, climate, cultivation methods and the potentiality of the soil [20]. Many research studies such as that of [33] who worked on different types of vegetables produced from various soil types had made similar observation as obtained in this work.

\section{CONCLUSION}

Current dietary guidelines to combat chronic diseases, such as cancer and coronary artery disease, recommend increased intake of plant foods, including fruits and vegetables, which are rich sources of antioxidants, and many studies have shown that a close relation exists between the intake of vegetables and cancer prevention. Therefore, tomato as one of the most versatile and widely used food plants could play an important role in human diet. These local varieties grown in Dutsin-ma are also good source of nutrient (Dan-eka and Dan-Masari) with no significant difference in the physiological quality parameters such as moisture, ash, fat, carbohydrate, protein, minerals vitamins and lycopene content with the one (UTC) been imported. However, all the three cultivars indicated high lycopene and vitamin content which can meet the daily intake for man, but Dan-eka shows higher content of the lycopene and the vitamin content which makes it the best of these cultivars. However these three cultivars can provide good industrial raw material for tomato paste production because their total solid are within the range of specification and also can meet daily recommended intake of lycopene and vitamin (A and $\mathrm{C}$ ) and also the low fat values for these samples also has nutritional implication, as they could also be used as a component of low diet for many patients who are placed on low fat diets.

It is recommended that techniques and methods of preservation of these tomatoes should be developed to avoid wastage as a result of high market glut during its harvesting seasons. It is also recommended that there should be increase in the production of tomato in Dutsin-ma especially Dan-eka, Dan-masari and others because of the potency of the soil and 
richness of other environmental factors in the area. Finally, a research is recommended to find out possible heavy metals in these varieties.

\section{REFERENCE}

[1] Aoun, A.B., Lechiheb, B., Benyahya, L. and Ferchichi, A. (2013) Evaluation of fruit quality traits of traditional varieties of tomato (Solanumlycopersicum) grown in Tunisia. African Journal of Food Science, 7(10): 350-354.

[2] Umeh, V. C., Kuku, F. O., Nwanguma, E. I., Adebayo, O. S. and Manga, A. A. (2002). A survey of the Insect Pests and Farmers Practices in the Cropping of Tomato in Nigeria.Tropicultura.20:181186.

[3] Denton, O. A. and Swarup, V. (2008). Tomato cultivation and its potential in Nigeria. Acta Horticulturae, 123, 257-263.

[4] Adelana, B. O. (2007). Effect staking on growth and yield of tomatoes, East African Journal of Science, 41(3): 243-249.

[5] Tee, E. S., Mohd Ismail, N., MohdNasir, A., and Kahtijah, I. (2009). Nutrient composition of Malaysian foods, 4th Edition, Malaysian Food Composition Database Programme, Institute for Medical Research, Kuala Lumpur, pp.310.

[6] Nielsen, S.S. (2002). An Introduction to the Chemical Analysis of Food.Satish Kumar Jain for CBS Publishers and Distributiors, 459611A, 11 Darya Ganj, New Delhi (India). Pp 83-175.

[7] Rodriguez-Amaya, D.B., and Kimura, M. (2004). Harvest plus handbook for carotenoid analysis in Harvest plus Technical Monograph, Series 2; International Food Policy Research Institute and International Center for Tropical Agriculture: Washington, DC, USA.

[8] Krinsky, N.I., and Yeum, K.J. (2005). Carotenoidradica interactions. Biochemical and Biophysical Research Communication, 305:754-760.

[9] Unlu, N.Z., Bohn, T., Francis, D. M., Nagaraja, H.N., Clinton, S.K., and Schwartz, S.J. (2007). Lycopene from heat indiced Cisisomer rich tomato sauce is more available than all trans-isomer rich tomato sauce in human. Journal of Nutrition, 98: 140-146.

[10] Naika, S., J. vanLidt de Jeude., M. de Goffau., M. Hilmi and B.van Dam. (2005). Cultivation of tomato production, processing and marketing.CTA.Series no 17.

[11] Thrumbo, P.R. (2005). Are there adverse effects of lycopene exposure? Journal of Nutrition, 135: 2060-2061.

[12] Akanbi, C. and Oludemi, F. (2004). Effect of processing and packaging on the lycopene content of tomato products. International Journal of Food Properties. 7(1): 139-152.

[13] Adedeji, O., Taiwo, K. A., Akanbi, C. T. and Ajani, R. (2006). Physicochemical properties of four tomato cultivars grown in Nigeria.Journal of food processing and preservation. 30(1):79-86.

[14] https://en.m.wikipedia.org/wiki/Dutsin-Ma.

[15] AOAC, (2005). Official Methods Analysis. Association of Official Analytical Chemist. Washington, D. C. U.S. A.

[16] Owusu, J., Haile, M., Wang, Z., and Amissah, A. (2012). Effect of drying methods on physicochemical properties of pretreated tomato (Lycopersicon esculentum mill.) slices. Journal of Food Technology, Biotechnology and Nutrition 7(1-2): 106111.

[17] Mohammed, S.M., Abdurrahman, A.A. and Attahiru M. (2017). Proximate Analysis and Total Lycopene Content of Some Tomato Cultivars Obtained from Kano State, Nigeria Chem Search Journal, 8(1): 64 - 69. http://dx.doi.org/10.4314/csj.v8i1.9.

[18] Sahin, F.H., Ulger, P. Aktas, T. and Orak, H. (2010). Effects of Different Drying Techniques of Some Nutritional Components of Tomato (Lycopersicum esculentum). Journal of Agricultural Machinery Science, 6(1), 71-78.

[19] Hossain, M.E., JahangirAlam, M., Hakim, M.A., Amanullah, A.S.M., and Ahsanullah, A.S.M. (2010). An assessment of physicochemical properties of some tomato genotypes and varieties grown at Rangpur. Bangladesh Research Publications Journal, 4(3): 235-243.

[20] Badejo, A. A., Adebowale, A. P., Enujiugha, V. N. (2016). Changes in Nutrient Composition, Antioxidant Properties and Enzyme Activities of Snake Tomato (Trichosanthes cucumerina) during ripening. Journal of Nutrition and. Food Science, 21 (2): 90 - 96.

[21] Adubofuor, J., Amankwah, E.A. Arthur, B.S., and Appiah, F. (2010). Comparative study related to physic-chemical properties and sensory attributes of tomato juice produced from oranges, tomatoes and carrots. African journal of Food Science, 4(7): 427-433.
[22] Suleiman, A.E., Awin, K.M.A., and Yousif, M.T. (2011). Suitability of some tomato (lycopersiconesculentum Mill). Genotypes for paste production. Journal of Science and Technology 12(2): 45-51.

[23] Campos, C. A. B., Fernandes, P. D., Gheyi, H. R., Blanco, F. F., Goncalves, C. B. and Campos, S.A.F. (2006). Yield and fruit quality of industrial tomato under saline irrigation. Science Agric, 2:63 - 69.

[24] Sobowale, S.S., Olatidoye, O.P., Odunmbaku, L.A. and Raji, O.H. (2012). A comparative study on physicochemical and rheological properties of imported tomato paste in Nigeria. Sustainable Agriculture Research, 1(2): 51.

[25] Arslan, D. and Özcan, M.M. (2011). Drying of tomato slices: changes in drying kinetics, mineral contents, antioxidant activity and colour parameters. Journal of Food, 9(3): 229-236.

[26] Ismail, I. A., Nasiru, A., Abdullahi, M. A. and Abdullahi, S.I. (2016). Proximate, mineral and vitamin analysis of fresh and canned Tomato. Vol 1163-1169.

[27] Hongyan, Q., Hua, L., Zhao, L. and Zhou, L. (2011). Carbohydrate Metabolism in Tomato (Lycopersicon esculentum mill.) Seedlings and Yield and Fruit Quality as Affected by Low Night Temperature and Subsequent Recovery. African Journal of Biotechnology 10(30), 57435749. http://www.academicjournals.org/AJB.

[28] Gould, W.A. (2004). Tomato production, Processing and Technology Baltimore, USA: CTI Publications.

[29] Leoni, C. and Jongen, W. (2003). Improving the nutritional quality of processed fruits \& vegetables: the case of tomatoes. Fruit and vegetable processing: improving quality pp52-66.

[30] Theeranat S. (2016). Analyzing Lycopene Content in Fruits. Agriculture and Agricultural Science Procedia 11 (2016) 46- 48.

[31] Etminam, M., Takkouche, B. and Caamano-Isorna, F. (2004). The role of tomato products and lycopene in the prevention of prostate cancer: A meta analysis of observational studies. Cancer Epideomology biomarkers and prevention, 13(3):340-5.

[32] Abdullahi, I.I., Abdullahi, N., Abdu, A.M. and Ibrahim, A.S. (2016). Proximate, Mineral and Vitamin Analysis of Fresh and Canned Tomato. Biosciences Biotechnology Research Asia, 13(2): 1163-1169.

[33] Umoh, G.S. (2006). Resource Use Efficiency in Urban Farming: An Application of Stochastic Frontier Production Function. International Journal of Agriculture and Biology, 8(1), 37-44.

[34] USDA (United States Department of Agriculture), National Nutrient Databases for Standard Reference, Release 20, 2007

[35] Harry, W.J. Encyclopaedia of Agricultural Science, volume V S-W. Index. (1994); pp 337-349.

[36] Romain, H.R. (2001). Crop production in Tropical Africa. CIP Royal library Albert I, Brussseis. pp. 467-475.

[37] Arvanitoyannis, I.S., Vaitsi, O. and Mavromatis, A. (2008). Potato: a comparative study of the effect of cultivars and cultivation conditions and genetic modification on the physicochemical properties of potato tubers in conjunction with multivariate analysis towards authenticity. Critical Reviews in Food Science and Nutrition, 48(9): 799- 823.

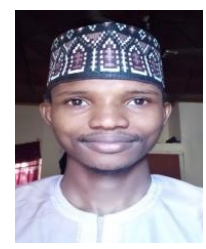

Zubairu Kaida Idris was born on the $10^{\text {th }}$ of October 1993 in Jibia local government area of Katsina state Nigeria. Zubairu obtained primary school certificate in 2006 and proceeded to government technical college Ingawa where he completed his secondary school in 2012. In 2013, Zubairu joined Federal University Dutsin-Ma Katsina and studied Bachelor of Food Science and Technology where he graduated with first class honors in 2018. Zubairu is currently pursuing his M. Tech in Food Science and technology.

$\mathrm{He}$ has worked with many different food companies across the state. He served as general manager of Kaida Bakery Jibia, as assistant sales manager in Maidabino Investment Limited and many small scale agro-allied ventures apart from his own agribusiness and other tradings.

Zubairu presently has a student membership in the Nigerian Institute of Food Science and Technology (NIFST) and participated in many seminars and conferences. He published journal papers in an international journal of food science and international journal of natural sciences, a conference paper in the NIFST annual conference 2019. A guest reviewer in some international journal publishers such as Premier Publishers. 